Article

\title{
Applying the UTAUT2 Model to a Non-Technological Service: The Case of Spa Tourism
}

\author{
Noelia Araújo Vila ${ }^{1, * \mathbb{C}}$, Jose Antonio Fraiz Brea ${ }^{1}\left(\mathbb{D}\right.$ and Jorge Pelegrín Borondo ${ }^{2}(\mathbb{D}$ \\ 1 Faculty of Business and Tourism, University of Vigo, 32004 Ourense, Spain; jafraiz@uvigo.es \\ 2 Department of Economics and Business, University of La Rioja, 26006 Logroño, Spain; \\ jorge.pelegrin@unirioja.es \\ * Correspondence: naraujo@uvigo.es
}

check for updates

Citation: Araújo Vila, N.;

Fraiz Brea, J.A.; Pelegrín Borondo, J. Applying the UTAUT2 Model to a Non-Technological Service: The Case of Spa Tourism. Sustainability 2021, 13, 803. https://doi.org/10.3390/ su13020803

Received: 22 December 2020 Accepted: 12 January 2021 Published: 15 January 2021

Publisher's Note: MDPI stays neutral with regard to jurisdictional clai$\mathrm{ms}$ in published maps and institutional affiliations.

Copyright: (C) 2021 by the authors. Licensee MDPI, Basel, Switzerland. This article is an open access article distributed under the terms and conditions of the Creative Commons Attribution (CC BY) license (https:// creativecommons.org/licenses/by/ $4.0 /)$.

\begin{abstract}
Well-being tourism is a $\$ 639$ billion market. Spa tourism is considered the most important segment within this market. The present study uses the Unified Theory of Acceptance and Use of Technology (UTAUT2) model to analyse tourists' purchase intentions regarding a thermal suite. The model was originally designed to analyse users' acceptance of new technologies. The original contribution of this paper is to apply it to a non-technological service. Specifically, data were collected through a questionnaire administered to a sample of 810 potential Spanish spa-goers. A consistent partial least squares (PLSc) SEM technique was used. The proposed model explains 53.3\% of the variance in Purchase Intentions regarding the thermal suite. Performance expectancy is the variable that plays the greatest role in tourists' purchase intentions, followed by hedonic motivation.
\end{abstract}

Keywords: well-being; spa; UTAUT2; decision making

\section{Introduction}

The well-being industry is a growing multi-trillion dollar a year global business [1]. Within this market, the specific segment of spa tourism is particularly promising and is expected to grow continuously in coming years [2]. This points to the existence of a significant demand for relaxation [3,4] and recovery from stress [5-8] through the consumption of spa services. According to the Global Wellness Institute [9], well-being tourism is a $\$ 639$ billion market today, and it is expected to reach $\$ 919$ billion by 2022 . The market grew $5.4 \%$ in 2017 , almost twice as fast as general tourism (3.2\%). This corresponds to 830 million well-being trips and accounts for $17 \%$ of overall tourism expenditures. Moreover, international wellbeing tourists spend an average of $\$ 1528$ per trip, 53\% more than the typical international tourist. Similarly, domestic well-being tourists spend $\$ 609$ per trip, $178 \%$ more than the average domestic tourist. Aiming to capitalise on this emerging market, many national tourism organisations have started to use well-being tourism as a major resource in their promotional campaigns [10]. In this context, they often highlight spas, as they are the most well-known type of well-being facility [11]. Tourism gives water resources great potential, because it facilitates the development of such attractive resources [12].

As in any tourism segment, spa-tourism service providers need to adapt their offer to their customers' requirements. Otherwise, they will most likely lose them to competitors whose services are more in tune with current market demands $[13,14]$. Therefore, knowing potential spa tourists' purchase intentions is of utmost importance to both practitioners and destination management organisations (DMOs). However, studies focusing on this topic are scarce; to the authors' knowledge, none uses causal models to analyse spa purchase intention. Only two papers analyse spa choice: Virabhakul and Huang [15], who used a joint analysis of cards with spa characteristics (comparison of two spas with two possible combinations of characteristics), and Ahani, Nilashi, Ibrahim, Sanzogni and Weaven [16], who used a machine-learning approach to analyse TripAdvisor comments and ratings. In this context, the present study uses the Unified Theory of Acceptance and Use of Technology 
(UTAUT) [17] and, more specifically, an adaptation of the UTAUT2 [18] to explain potential tourists' purchase intentions regarding a thermal suite. Originally designed to explain the acceptance of new technologies, the UTAUT models are essentially based on the Technology Acceptance Models (TAM and TAM2) [19,20], the Theory of Reasoned Action (TRA) [21] and the Theory of Planned Behaviour (TPB) [22].

The UTAUT models have been widely used in the context of new technologies, but they have rarely been applied to non-technological services. In the present study, the UTAUT2 model is used to analyse potential tourists' purchase intentions regarding a thermal suite (non-technological service). Their ability to explain the intention to use such services is, thus, unknown. In this regard, the theoretical contribution of the present study is twofold. First, it addresses customers' purchase intentions with regard to Spa services, a topic that has not received enough academic attention. Second, it empirically tests the UTAUT2 model's potential to explain purchase intentions regarding a non-technological service, which likewise has not been addressed in the academic literature. In this context, the application of the model to a non-technological service, namely, Spa facilities and services, increases the study's originality.

\section{Theoretical Background}

In the context of the wellness society, the following two concepts are central to the present research and, thus, need to be precisely defined [23]:

(i) Well-being: understood as the harmony between body and mind. It includes cosmetic procedures, relaxation, healthy diets and social relationships [24-26]. The media frequently associate well-being with tasteful, current and stylish products. In the context of tourism, it has been defined as 'a phenomenon to enhance personal wellbeing for those traveling to destinations which deliver services and experiences to rejuvenate the body, mind and spirit' [27].

(ii) Spa: any facility offering services that use water for health and/or well-being purposes. The concept is not limited to the traditional conception of a water resort, as it also includes relaxation and well-being services that help customers achieve a balance between their physical, emotional and social relationships and intellectual needs $[1,28]$.

Spa tourism has emerged as the link between these two trends-well-being and spas-in the well-being society. In this regard, some tourists seek out well-being facilities, typically spas, during their trips. They use these establishments for enjoyment or well-being purposes, not to cure disease $[26,29,30]$.

Campón-Cerro et al. [31] said in their study that the scientific literature on tourism identifies two driving trends: the quest for experientiality and the growing connection between holidays and quality of life. The importance of combining two dimensions-health and wellness-in spas $[2,26]$ has been highlighted in numerous studies in several countries, such as Finland [32], Greece [33], Jamaica [34], Japan [29], Taiwan [35,36] and the United States of America [3].

\section{Conceptual Framework and Hypothesis Development}

The present research is based on the UTAUT2 model [18]. The UTAUT models [17] and their predecessors—the Technology Acceptance Models (TAM) [19,20] — have been widely used to explain behavioural intentions regarding technological products, such as the use of smartphones [37]. They have also been used, albeit to a lesser extent, to explain behavioural intentions in the context of technological services, such as tourists' use of online travel reviews [38] or green technology use behaviour in the hospitality industry [39]. In the present study, the UTAUT2 model is used to analyse potential tourists' purchase intentions regarding a thermal suite (non-technological service). The following sections address the theoretical background for the variables included in the proposed model. 


\subsection{Performance Expectancy and Effort Expectancy}

Performance expectancy is defined as the degree to which a person considers that using a specific technology would be useful to enhance their performance, whilst effort expectancy is the degree of ease associated with the use of a specific technology [17].

In the context of spas, spas' health-related benefits, that is, their usefulness for improving one's health, are one of the aspects most often addressed in the literature on the topic [40]. Koh et al. [3] concluded that health benefits and rejuvenation are the most important spa selection criteria for spa tourists in the United States. Hsieh [35] concluded that one of the four most important motivational factors for Taiwanese spa tourists is 'arranged treatment'. Kamenidou et al. [33] identified therapeutic reasons, body care/pampering and escape from routine as motivational factors for spa tourists. Analysing the case of Jamaican Spa tourists, Valentine [34] highlighted the utility of natural treatments using air and water, rest and healthy diets. Finally, Kucukusta and Guillet [41] pointed to the therapist's qualifications as the variable that most influences tourists' choice of spa, as they are viewed as indicative of the benefit the treatment will provide. Likewise, Han, Kiatkawsin, Jung and Kim [42] concluded that the performances of well-being spa tourism in Thailand significantly influence overall satisfaction with well-being spa tourism destinations.

Few studies have analysed the ease-of-use construct in the context of spas. Amongst those that have, Alén et al. [43] highlighted 'friendly treatment' as one dimension of Spanish spa customers' expectations. Other studies have demonstrated the importance of ease of use for the selection of health-care technologies. For instance, Chiu and Ku [44] compared the contexts in which users must use a certain technology with those in which they can decide whether or not to use it. Yoon et al. [45], in turn, looked at ease of use in the context of a massage-booking technology.

Based on these contributions, the following hypotheses are proposed:

Hypothesis 1 (H1). Performance expectancy regarding a thermal suite positively affects potential tourists' purchase intentions.

Hypothesis 2 (H2). Effort expectancy regarding a thermal suite positively affects potential tourists' purchase intentions.

\subsection{Social Influence}

In the context of technological products, social influence is defined as the degree to which a person perceives that others believe that they should use a specific technology [17].

In relation to spas, many authors $[3,35]$ considered the social aspect (socialising and building relationships) to be one of the most important reasons to go to spas. Indeed, other people's opinions have been shown to be of great importance in the selection of a spa. Klaysung [46] highlighted the importance of positive reviews from friends and acquaintances in the Spa-selection process, whilst Kamenidou et al. [33] identified both friends' and family members' recommendations and doctors' recommendations as essential aspects in the choice of spa.

Based on these contributions, the following hypothesis is proposed:

Hypothesis 3 (H3). Social influence in favour of a thermal suite positively affects potential tourists' purchase intentions.

\subsection{Facilitating Conditions}

In the context of technological products, facilitating conditions have been defined as the degree to which a person believes that they have the necessary organisational and technical infrastructure to use a specific technology [17].

Specifically, in the context of spas, many studies have demonstrated the importance of facilitating conditions for choosing a spa during a trip. Klaysung [46], for instance, highlighted parking space availability and the absence of traffic jams as important spa- 
selection criteria for tourists in Thailand. The same author also underlines the importance of courteous staff, as courteousness reinforces the idea that they will be available to help customers when necessary. Lee and King [36] conclude that Taiwanese spa tourists seek privacy, safety and protection (i.e., a place where it is safe to drink and bathe in the hot-spring water, that has good sanitation, etc.) when choosing a spa.

In view of these contributions on facilitating conditions, the following hypothesis is proposed:

Hypothesis 4 (H4). The perception of facilitating conditions for the use of a thermal suite positively affects potential tourists' purchase intentions.

\subsection{Hedonic Motivation}

Hedonic motivation is defined as the perceived fun or pleasure derived from the use of a technology and is considered a determinant factor of technology acceptance and use by consumers $[47,48]$.

In a few cases, the construct has also been applied to the more specific context of spa choice. For example, Kim et al. [49] concluded that spa-goers seem to receive hedonic benefits, as spas are a unique product providing unique services. Voigt et al. [50] investigated whether tourism experiences can be classified as hedonic or eudaimonic, to which end they collect testimonials from three groups of well-being tourists: visitors to beauty spas, lifestyle-tourism complexes and spiritual retreats. Additionally, Johanson [51] showed that $45 \%$ of women and $26 \%$ of men who visit spas do so because they 'felt like splurging'. Likewise, several studies $[1,3,26,33]$ pointed to relaxation as one of the most important aspects considered by tourists when choosing a spa, and Hsieh [35] concluded that feeling good is one of the four main motivations for Taiwanese spa tourists.

In light of these contributions on hedonic motivations, the following hypothesis is proposed:

Hypothesis 5 (H5). Hedonic motivations for going to a thermal suite positively affect potential tourists' purchase intentions.

\subsection{Price Value}

Price value is related to price perception, understood as the customer's perception of whether a product is expensive (perceived price loss) or cheap (perceived price gain) [52]. The more expensive a product is, the lower the probability of purchase; the cheaper it is, the greater the probability of purchase. However, the price-value variable has a two-fold effect on purchase likeliness: a positive effect, insofar as it is an indicator of quality; and a negative effect, due to consumers' budget constraints. Both effects influence the purchase decision [53]. Pelegrín-Borondo et al. [52] concluded that this dual effect also applies to the context of tourism.

With regard to the choice of therapeutic facilities and services, the few studies addressing the role of price [11] concluded that there is a set of socioeconomic factors that affect consumers' decisions [54]. Of these, income is the most influential variable and, consequently, a determinant factor for consumers' decisions regarding discretionary time expenditure.

As for the influence of price on the choice of spa, studies show that wealthier individuals are most likely to consume this type of service, indicating a positive correlation between income and activity participation [55]. In this vein, Klaysung [46] concludes that a good price is one of the most important aspects when choosing a spa. More specifically, Kucukusta, Pang and Chui [56] showed that price is particularly important for certain demographic groups (aged 36 to 45; graduate-level or higher degree). Virabhakul and Huang [57] concluded that perceived value significantly influences behavioural intentions in a well-being spa service context. The results of Kucukusta, Pang and Chui [56] showed that price was considered to be very important in respondents' hotel spa selection because price always affects people's choices. 
In light of these contributions on the role of price in spa choice, the following hypothesis is proposed:

Hypothesis 6 (H6). The price value of the thermal suite positively affects potential tourists' purchase intentions.

\subsection{Habit}

Many researchers have stated that habits influence consumers' behaviour in tourism and leisure contexts [58,59]. Habit is associated with unconscious psychological attributes that foster consistency between past and present behaviours [60]. Therefore, habit includes automaticity, spontaneity and resistance, which, in turn, lead to frequent behaviour [61]. The term is not commonly used in the context of leisure and tourism. However, it has been applied in other contexts, such as sport and exercise, in which habit might predict behaviour and tends to foster both exercise [62] and nutrition [63] patterns. In both cases, the habitual actions promote health and good shape.

This phenomenon has also been considered in a few studies addressing the role of habit in consumers' decisions in the context of well-being tourism. For instance, Mak et al. [8] observed that Hong Kong wellness tourists have the habit of regularly going to spas. Other studies looked at the personal health habits and well-being practices of American surgeons [64] and addressed wellness tourism from the perspective of stress alleviation or indulging healthy habits [6]. Therefore, there are theoretical antecedents to the analysis of habit as a determinant factor of well-being tourists' behaviour, although to a much lesser extent than in other industries.

Based on these contributions on the role of habit, the following hypothesis is proposed:

Hypothesis 7 (H7). Consumers' habit of going to spas affects their purchase intentions regarding a thermal suite.

The conceptual model, including all the addressed variables and the proposed hypotheses, is graphically represented in Figure 1.

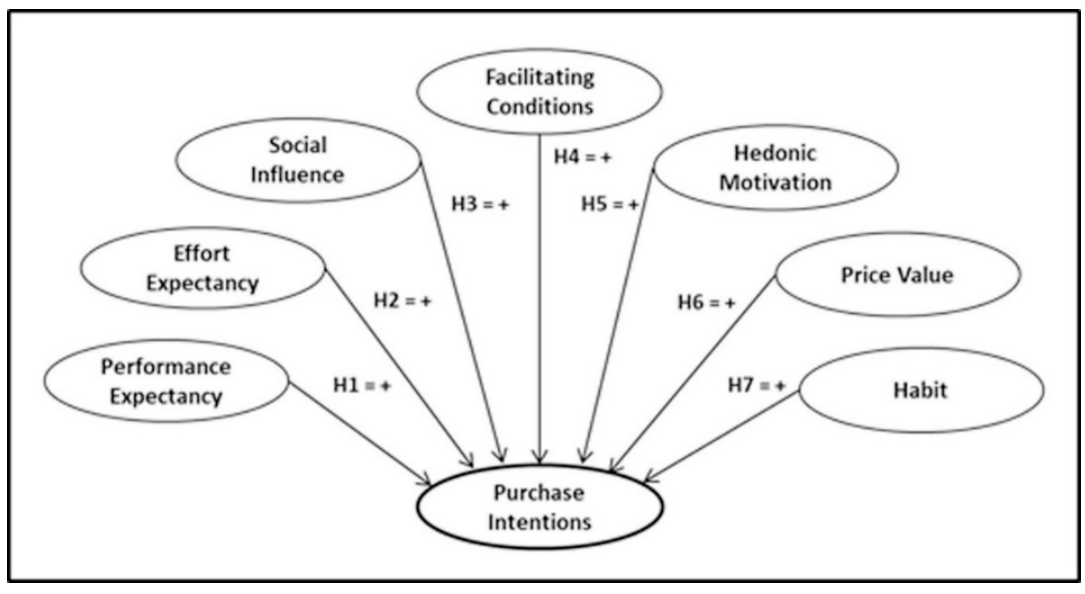

Figure 1. Conceptual model.

\section{Method}

\subsection{Data Collection}

To achieve the present study's objectives, data were collected through a survey administered to a sample of potential Spanish tourists and stratified by gender ( $50 \%$ women) and age (20\% for each age range; see Table 1$)$. 
Table 1. Technical details of the data collection and sample characterisation.

\begin{tabular}{cc}
\hline Research Universe & Spanish Residents Who Do Not Live in Pantón \\
\hline Data collection method & Quantitative survey, administered face-to-face or via telephone \\
Sample & 810 people \\
Data collection period & March and April 2019 \\
& Sample characteristics \\
Gender & Women: $50 \%$ \\
& 20 to 30 years old: $20 \%$ \\
& 31 to 40 years old: $20 \%$ \\
Age & 41 to 50 years old: $20 \%$ \\
& 51 to 60 years old: $20 \%$ \\
& 61 years old or more: $20 \%$ \\
No formal education: $3.5 \%$ \\
Primary school: $27.7 \%$ \\
Formal education & Secondary school: $32.2 \%$ \\
& Higher education: $36.5 \%$ \\
\hline
\end{tabular}

The spa Oca Augas Santas Balneario \& Golf Resort (Pantón, Lugo, Galicia) was used as a reference establishment for the data collection. The spa is located in Galicia. Galicia has over 300 hot springs, making it the biggest spa destination in Spain, as well as one of Europe's richest regions in terms of mineral and hot springs [65]. Moreover, Spain is one of the 12 European countries in the 2017 ranking of the world's top 20 well-being tourism destination markets; the country ranks 15 th, with 18.8 million trips a year. With so many countries in the top 20, Europe is the continent with the most well-being trips: 292 million in 2017 [9].

The data collection procedures were carried out by trained researchers, who contacted people that fit the pre-defined profile (gender and age ranges) and were not residents of the spa's location (Pantón, Lugo). To find suitable respondents, a snowball approach was used. Specifically, researchers first contacted people from their own networks, who were then asked to provide the contact details of other people who fit the pre-defined profile. The surveys were administered either face-to-face or via telephone. Prior to taking the survey, respondents were shown a 45-s video featuring images of the hotel (exterior locations, rooms, golf course) and the thermal suite (outdoor and indoor facilities). They were also given a document with a real spa offer, in which two hours' use of the thermal suite was listed as costing 21 euros (tax included). The offer showed the thermal-suite facilities that could be used. In the cases in which the survey was administered via telephone, the video and offer were sent to the respondents previously via e-mail. In this context, achieving an adequate sub-sample of respondents from higher age groups was particularly challenging. After showing the video, the researcher asked the questions from the survey and thanked the respondent for their participation.

Of the original set of collected responses, those presenting inconsistencies or errors were discarded, resulting in a final sample of 810 valid questionnaires. The sample's characteristics are summarised in Table 1.

The constructs were adapted from the UTAUT2 model [18]. All constructs were operationalised through an 11-point Likert scale ranging from 0 (do not agree at all) to 10 (totally agree). The measurement items used to assess the model's variables are summarised in Table 2. 
Table 2. Scale items used to measure the model's variables.

\begin{tabular}{|c|c|c|}
\hline Construct & Items & Source \\
\hline Performance Expectancy (PE) & $\begin{array}{l}\text { PE1. Using the thermal suite would be useful to me. } \\
\text { PE2. Using the thermal suite would increase my chances of achieving } \\
\text { things that are important to me. } \\
\text { PE3. Using the thermal suite would help me achieve my goals faster. } \\
\text { PE4. Using the thermal suite would increase my quality of life. }\end{array}$ & \multirow{4}{*}{$\begin{array}{c}\text { Adapted from } \\
\text { Venkatesh et al. [17] }\end{array}$} \\
\hline Effort Expectancy (EE) & $\begin{array}{l}\text { EE1. It will be easy for me to learn how to use the thermal suite. } \\
\text { EE2. For me, how to use the thermal suite will be clear } \\
\text { and comprehensible. } \\
\text { EE3. It will be easy for me to use the thermal suite. } \\
\text { EE4. It will be easy for me to be an expert in using the thermal suite. }\end{array}$ & \\
\hline Social Influence (SI) & $\begin{array}{l}\text { SI1. The people who are important to me would think that I should } \\
\text { use the thermal suite. } \\
\text { SI2. The people who influence me would think that I should use the } \\
\text { thermal suite. } \\
\text { SI3. The people whose opinions I value would like me to use the } \\
\text { thermal suite. }\end{array}$ & \\
\hline Facilitating Conditions (FC) & $\begin{array}{l}\text { FC1. I have the necessary resources (i.e., time and money) to use the } \\
\text { thermal suite. } \\
\text { FC2. I have the necessary knowledge to use the thermal suite. } \\
\text { FC3. The thermal suite will be compatible with other activities that I } \\
\text { might engage in whilst at the spa. } \\
\text { FC4. I will get help from the spa's staff if I have any difficulty using } \\
\text { the thermal suite. }\end{array}$ & \\
\hline Hedonic Motivation (HM) & $\begin{array}{l}\text { HM1. Using the thermal suite will be fun. } \\
\text { HM2. Using the thermal suite will be pleasant. } \\
\text { HM3. Using the thermal suite will be entertaining. }\end{array}$ & \multirow{3}{*}{$\begin{array}{c}\text { Adapted from } \\
\text { Venkatesh et al. [18] }\end{array}$} \\
\hline Price Value (PV) & $\begin{array}{l}\text { PV1. The thermal suite is reasonably priced. } \\
\text { PV2. The thermal suite has a good price/quality ratio. } \\
\text { PV3. The thermal suite offers good value. }\end{array}$ & \\
\hline Habit $(\mathrm{H})$ & $\begin{array}{l}\text { Hypothesis } 1(\mathrm{H} 1) \text {. I am used to using thermal suites. } \\
\text { Hypothesis } 2(\mathrm{H} 2) \text {. I am addicted to using thermal suites. } \\
\text { Hypothesis } 3(\mathrm{H} 3) \text {. I think I must use thermal suites. } \\
\text { Hypothesis } 4 \text { (H4). Using thermal suites is natural to me. }\end{array}$ & \\
\hline
\end{tabular}

\subsection{Data Analysis}

The collected data were analysed with structural equation modelling (SEM). More specifically, the consistent partial least squares (PLSc) SEM technique was used. Unlike partial least squares (PLS), PLSc is less sensitive to Type I and Type II errors and should be used with models in which all constructs are reflective [66], as in the present case. Moreover, PLS tends to skew factor loadings upwards and underestimate regression coefficients [67]. Both PLS and PLSc SEM techniques are less sensitive to the violation of assumptions of data normality than other SEM techniques [68]. Furthermore, PLSc is adequate for research intended to predict or explain a phenomenon [37], as in the present study.

\section{Results}

\subsection{Assessment of the Measurement Model}

The SEM results indicate that all the scale items are reliable: all standardised loadings were higher than 0.7 and all $\mathrm{t}$-values were higher than 1.96 [69]. However, for five specific items, the initial standardised loadings did not meet this condition. Consequently, one item from the Facilitating Conditions scale (item FC1) was eliminated. The other four items were kept, as their $\mathrm{t}$-values were higher than 1.96. Moreover, as noted by Chin [70], the 0.7 standardised loading rule is flexible, particularly when indicators contribute to a factor's content validity, which further supports this decision. 
All the constructs also had composite reliability and Cronbach's alpha values higher than 0.7 (Table 3), indicating that they are in fact reliable. With regard to convergent validity, the average variance extracted (AVE) was 0.5 or higher for all constructs except Facilitating Conditions, which needed a one-decimal adjustment to fulfil this criterion. As for discriminant validity, the Fornell-Larcker criterion was fulfilled, as in all constructs except Facilitating Conditions and Effort Expectancy, the AVE's square root was greater than the correlations between constructs. As the variable Effort Expectancy had greater reliability and convergent validity than the variable Facilitating Conditions, the latter was eliminated from the model. Table 4 shows the updated discriminant validity results once the Facilitating Conditions construct had been excluded: the Fornell-Larcker criterion is fulfilled, and the HTMT (heterotrait-monotrait ratio of correlations) values used to measure discriminant validity are less than 0.9 in all cases, indicating satisfactory reliability and discriminant validity.

Table 3. Construct reliability and convergent validity.

\begin{tabular}{cccc}
\hline Construct & Composite Reliability & Cronbach's Alpha & AVE \\
\hline Performance Expectancy (PE) & 0.89 & 0.89 & 0.66 \\
Effort Expectancy (EE) & 0.91 & 0.91 & 0.72 \\
Social Influence (SI) & 0.95 & 0.95 & 0.87 \\
Facilitating Conditions (FC) & 0.71 & 0.72 & 0.47 \\
Hedonic Motivation (HM) & 0.90 & 0.90 & 0.74 \\
Price Value (PV) & 0.96 & 0.96 & 0.89 \\
Habit (H) & 0.88 & 0.87 & 0.62 \\
Purchase Intentions (PI) & 0.92 & 0.92 & 0.84 \\
\hline
\end{tabular}

Table 4. Discriminant validity.

\begin{tabular}{cccccccc}
\hline Construct & PE & EE & SI & HM & PV & H & PI \\
\hline Performance Expectancy (PE) & 0.81 & 0.20 & 0.76 & 0.52 & 0.40 & 0.61 & 0.66 \\
Effort Expectancy (EE) & 0.20 & 0.85 & 0.25 & 0.47 & 0.32 & 0.29 & 0.34 \\
Social Influence (SI) & 0.75 & 0.25 & 0.93 & 0.45 & 0.38 & 0.51 & 0.53 \\
Hedonic Motivation (HM) & 0.53 & 0.47 & 0.45 & 0.86 & 0.44 & 0.43 & 0.57 \\
Price Value (PV) & 0.40 & 0.32 & 0.38 & 0.44 & 0.94 & 0.30 & 0.43 \\
Habit (H) & 0.63 & 0.29 & 0.53 & 0.45 & 0.31 & 0.79 & 0.49 \\
Purchase Intentions (PI) & 0.67 & 0.34 & 0.53 & 0.57 & 0.43 & 0.50 & 0.92
\end{tabular}

Note: Diagonal elements in bold are the square root of the average variance extracted (AVE). The elements below the bold numbers are the correlations amongst the constructs. The elements above the bold numbers are the HTMT (heterotrait-monotrait ratio of correlations) values.

Finally, the collinearity between the exogenous variables to Purchase Intentions (i.e., Performance Expectancy, Effort Expectancy, Social Influence, Facilitating Conditions, Hedonic Motivation, Price Value and Habit) were assessed. Performance Expectancy had the highest Variance Inflation Factor (VIF) value, at 3.06. This suggests that multicollinearity is not a concern in the present study, as according to the general statistics theory [71], only a VIF higher than 10 would be problematic.

\subsection{Assessment of the Structural Model}

Table 5 shows the effects of the exogenous variables on the variable Purchase Intentions. The applied UTAUT2 model had a determination coefficient (R2) of 0.53, indicating that the variables it encompasses explain 53\% of the variance in Purchase Intentions. Therefore, the model was deemed satisfactory. The model's predictive relevance was assessed through the Q2 provided by PLS predict, which had a value of 0.37 . This indicates that the exogenous variables do indeed relevantly predict the endogenous variable Purchase Intentions. It is worth noting that, had the variable Facilitating Conditions been kept, the model's R2 would be 0.54 , whilst its Q2 would still be 0.37 . Therefore, the variable's elimination did not affect the model's ability to explain the variances in the endogenous variable. 
Table 5. Effect on endogenous variable.

\begin{tabular}{|c|c|c|c|c|c|c|}
\hline & $\mathbf{R}^{2}$ & $Q^{2}$ & Direct Effect & $p$-Value & Correlation & $\begin{array}{l}\text { Variance } \\
\text { Explained }\end{array}$ \\
\hline Purchase intentions & 0.53 & 0.37 & & & & \\
\hline $\begin{array}{c}\text { Hypothesis } 1(\mathrm{H} 1) \text { : Performance Expectancy }(\mathrm{PE}) \geq \\
(+) \text { Purchase Intentions }\end{array}$ & & & 0.47 & $<0.00$ & 0.67 & $31.49 \%$ \\
\hline $\begin{array}{c}\text { Hypothesis } 2(\mathrm{H} 2) \text { : Effort Expectancy }(\mathrm{EE}) \geq \\
(+) \text { Purchase Intentions }\end{array}$ & & & 0.09 & 0.02 & 0.34 & $3.06 \%$ \\
\hline $\begin{array}{c}\text { Hypothesis } 3(\mathrm{H} 3) \text { : Social Influence (SI) } \geq \\
(+) \text { Purchase Intentions }\end{array}$ & & & -0.01 & 0.86 & 0.53 & $-0.53 \%$ \\
\hline $\begin{array}{c}\text { Hypothesis } 5(\mathrm{H} 5) \text { : Hedonic Motivation }(\mathrm{HM}) \geq \\
(+) \text { Purchase Intentions }\end{array}$ & & & 0.22 & $<0.00$ & 0.57 & $12.54 \%$ \\
\hline $\begin{array}{c}\text { Hypothesis } 6(\mathrm{H} 6) \text { : Price Value }(\mathrm{PV}) \geq \\
(+) \text { Purchase Intentions }\end{array}$ & & & 0.10 & 0.02 & 0.43 & $4.30 \%$ \\
\hline $\begin{array}{l}\text { Hypothesis } 7 \text { (H7): Habit }(\mathrm{H}) \geq \\
(+) \text { Purchase Intentions }\end{array}$ & & & 0.06 & 0.20 & 0.50 & $3.00 \%$ \\
\hline
\end{tabular}

Note: H4-Facilitating Conditions $(F C) \geq(+)$ Purchase Intentions was eliminated from the model due to discriminant validity problems with the exogenous variable.

Regarding the proposed hypotheses, the results show that Performance Expectancy had a significant positive effect on Purchase Intentions. Therefore, Hypothesis 1 (H1) is supported. Although to a lesser extent, Hedonic Motivation also significantly and positively affected Purchase Intentions. Therefore, support was also found for Hypothesis 5 (H5). The variables Effort Expectancy and Price Value exerted a weaker, but still significant, influence $(p=0.02)$ on Purchase Intentions, providing evidence to support Hypothesis 2 (H2) and Hypothesis 6 (H6), although with a lower degree of significance. Finally, Social Influence and Habit had no statistically significant effect on Purchase Intentions. In fact, Social Influence had a negative explained variance. Falk and Miller [72] explained that such an effect occurs 'when the original relationship between the two variables is so close to zero, the difference in the signs simply reflects random variation around zero'. In short, no support was found for Hypothesis 3 (H3) or Hypothesis 7 (H7).

\section{Discussion and Conclusions}

The UTAUT models have been widely used in the context of new technologies, but they have rarely been applied to non-technological services. The aim of this study was to propose a model that could explain potential tourists' purchase intentions in the context of spa tourism (non-technological service). The proposed model, based on the Unified Theory of Acceptance and Use of Technology (UTAUT2) [18], addresses the role of six exogenous variables on potential customers' purchase intentions with regard to a thermal suite. It was operationalised through the variable Purchase Intentions. The study's aim was fulfilled, as the proposed model explains 53.3\% of the variance in Purchase Intentions regarding the thermal suite.

The results show that the variable that exerts the greatest influence on purchase intentions regarding a thermal suite is Performance Expectancy. This finding is in line with previous studies, which have demonstrated that expected utility is one of the most important aspects when choosing a spa [3,33]. Hsieh [35] concluded that one of the four most important motivational factors for Taiwanese spa tourists is 'arranged treatment'. Valentine [34] highlighted the usefulness of natural remedies as a key factor for visiting a spa. In this context, the present study not only reinforces the importance of this factor but also shows that it is indeed the most important one in a model with an explanatory power (as indicated by the $\mathrm{R}^{2}$ value) of 0.53 . This finding is also consistent with the results reported by Kucukusta and Guillet [41], according to whom the therapist's qualification is the most influential variable for health tourists. In fact, such qualifications are an indicator of the utility of the treatment the therapist performs. Pelegrín-Borondo, Araújo-Vila and 
Fraiz-Brea [73] also concluded that performance expectancy is the most important variable for both wellness spa tourists and healthcare/medical spa tourists.

The next variable that best statistically explains potential tourists' purchase intentions regarding a spa is Hedonic Motivation, which explains $12.54 \%$ of the variance. The relevance of this variable was expected, as the literature has systematically shown that hot-spring waters have been used for both medicinal and leisure purposes [30]. Hsieh [35] concluded that feeling good is one of the four main motivations for spa tourists. Huh, Lee, and Lee [27] identified a spa-goer market segment that they call "pleasure pursuers".

In short, the two main reasons to visit spas are health (utility factor) and wellbeing/enjoyment (hedonistic factor) [3,33]. In this context, it is unsurprising that the variables related to these two aspects-Performance Expectancy (health-related utility) and Hedonic Motivation (wellness/enjoyment) - account for most of the explained variance in the variable Purchase Intentions ( $44.03 \%$ out of the $53.3 \%$ explained by the model).

The third variable in order of the amount of variance explained is Price Value. This finding is in line with previous studies [35]. The importance of having a reasonable price has been clearly addressed in the literature, in the context of both consumer goods [74] and spas [41]. However, this variable explained $4.3 \%$ of the total variance in purchase intentions and, therefore, is significantly less important than the first two. The result contradicts Klaysung [46], who concluded that a good price is one of the most important aspects when choosing a spa. Nevertheless, the present findings suggest that, although Price Value is important, two other factors (Performance Expectancy and Hedonic Motivation) are more decisive when choosing a spa.

With regard to Effort Expectancy, although previous studies [44,45] have shown that it is relevant in customers' choice of health-care technology, though few studies have addressed it in the context of spas [43]. In the present study, Effort Expectancy was found to exert an even smaller influence on Purchase Intentions (3.06\%). This is also unsurprising, as using thermal suites does not require a great amount of knowledge or effort. The customer simply has to move between the facilities that comprise the suite and does not even have to worry about turning them on or off. The most customers are required to do in some cases is press a button.

As for Social Influence, previous studies $[33,46]$ have suggested that other people's opinions were a determinant variable for potential customers' purchase intentions regarding spas. However, the present study's results suggest the opposite, as Social Influence was found to have no statistically significant influence on Purchase Intentions. Similarly, Kim, Kim, Huh, and Knutson [49] did not find social norms to have a significant influence. This might be because people are more inclined to value the opinions of experts over those of friends and family when it comes to health-related issues.

Finally, with regard to Habit, a few previous studies have addressed its influence on spa tourists' behaviour. Mak et al. [8], for instance, found that Hong Kong spa-goers have the habit of visiting spas regularly. Habit has indeed been found to have some influence on customer behaviour in the context of wellness products other than spas $[6,64]$. In the present study, however, it did not show any statistically significant capacity to explain purchase intentions.

\subsection{Managerial Implications}

Given that Performance Expectancy was the variable that most explained potential tourists' purchase intentions regarding a spa, the main implication of the present study's results for spa managers is the need to focus their communication on convincing potential customers of their services' utility. Additionally, they should not overlook the leisure aspect, since Hedonic Motivation was shown to be the second most influential variable. In this regard, both health and leisure aspects must be considered when formulating spas' marketing communication and designing thermal suites. 


\subsection{Limitations and Future Research}

The model proposed in this paper had discriminant validity problems with regard to the variables Effort Expectancy and Facilitating Conditions, resulting in the elimination of the latter. The former, however, was kept, as it had better reliability. This is a limitation of the study, as it prevented the authors from considering the effect of such facilitating conditions on potential customers' purchase intentions regarding the thermal suite. Future studies should assess the role of facilitating conditions in some other form.

The current COVID pandemic necessitates new adjustments to many well-being activities and purchasing decisions. In future research, the proposed model should be modified to include variables related to sense of health security or verification of health conditions.

Recently, Kowalczyk-Anioł and Nowacki [75] have concluded that the variable perceived enjoyment is important for younger generations. This paper has not considered intergenerational differences. Future research should check if there are differences in the proposed model according to age.

Author Contributions: Conceptualisation, J.P.B. and J.A.F.B.; methodology, J.P.B. and N.A.V.; software, J.P.B.; validation, J.P.B.; formal analysis, J.P.B. and N.A.V.; investigation, J.P.B. and J.A.F.B.; resources, J.A.F.B.; data curation, N.A.V. and J.A.F.B.; writing - original draft preparation, J.P.B., N.A.V. and J.A.F.B.; writing—-review and editing, N.A.V.; visualisation, J.P.B.; supervision, J.P.B.; project administration, J.P.B. All authors have read and agreed to the published version of the manuscript.

Funding: This research was funded by the COBEMADE research group at University of La Rioja (REGI 20/40) and "Programa RIS3 La Rioja. CAR-PID2019-105764RB-I00".

Institutional Review Board Statement: Not applicable.

Informed Consent Statement: Not applicable.

Conflicts of Interest: The authors declare no conflict of interest.

\section{References}

1. Baloglu, S.; Busser, J.; Cain, L. Impact of experience on emotional well-being and loyalty. J. Hosp. Mark. Manag. 2019, 28, 427-445. [CrossRef]

2. Rodrigues, H.; Brochado, A.; Troilo, M. Listening to the murmur of water: Essential satisfaction and dissatisfaction attributes of thermal and mineral Spas. J. Travel Tour. Mark. 2019, 37, 649-661. [CrossRef]

3. Koh, S.; Yoo, J.-E.; Boger, C.A., Jr. Importance-performance analysis with benefit segmentation of spa goers. Int. J. Contemp. Hosp. Manag. 2010, 22, 718-735. [CrossRef]

4. Pesonen, J.; Laukkanen, T.; Komppula, R. Benefit segmentation of potential wellbeing tourists. J. Vacat. Mark. 2011, 17, 303-314. [CrossRef]

5. Chen, C.C.; Petrick, J.F. Health and wellness benefits of travel experiences: A literature review. J. Travel Res. 2013, 52, 709-719. [CrossRef]

6. Hudson, S.; Thal, K.; Cárdenas, D.; Meng, F. Wellness tourism: Stress alleviation or indulging healthful habits? Int. J. Cult. Tour. Hosp. Res. 2017, 11, 35-52. [CrossRef]

7. Kelly, C. Wellness tourism: Retreat visitor motivations and experiences. Tour. Recreat. Res. 2012, 37, 205-213. [CrossRef]

8. Mak, A.H.; Wong, K.K.; Chang, R.C. Health or self-indulgence? The motivations and characteristics of spa-goers. Int. J. Tour. Res. 2008, 11, 185-199. [CrossRef]

9. Global Wellness Institute. Global Wellness Tourism Economy; GWI: Miami, FL, USA, 2018.

10. United Nations World Tourism Organization. Exploring Health Tourism; UNWTO: Madrid, Spain, 2018.

11. Atanga, C.A.; Amuquandoh, F.E.; Amenumey, E.K. Modelling spa-goers' choices of therapeutic activities. J. Hosp. Tour. Manag. 2017, 31, 105-113. [CrossRef]

12. Folgado-Fernández, J.A.; Di-Clemente, E.; Hernández-Mogollón, J.M.; Campón-Cerro, A.M. Water Tourism: A New Strategy for the Sustainable Management of Water-Based Ecosystems and Landscapes in Extremadura (Spain). Land 2018, 8, 2. [CrossRef]

13. Hashemi, S.M.; Jusoh, J.; Kiumarsi, S.; Mohammadi, S. Influence factors of spa and wellness tourism on revisit intention: The mediating role of international tourist motivation and tourist satisfaction. Int. J. Res. 2015, 3, 1-11.

14. Sinaga, S.; Mielniczak, A. Shall We Go to the Spa? The Spa Trends in Gothenburg and its Region. Master's Thesis, Göteborg University, Göteborg, Sweden, 2006.

15. Virabhakul, V.; Huang, C.H. How do spa-goers make decisions when faced with a choice conflict? Discrete choice experiments for day spas in Thailand. New Trends Issues Proc. Humanit. Soc. Sci. 2017, 4, 596-612. [CrossRef] 
16. Ahani, A.; Nilashi, M.; Ibrahim, O.; Sanzogni, L.; Weaven, S. Market segmentation and travel choice prediction in Spa hotels through TripAdvisor's online reviews. Int. J. Hosp. Manag. 2019, 80, 52-77. [CrossRef]

17. Venkatesh, V.; Morris, M.G.; Davis, G.B.; Davis, F.D. User acceptance of information technology: Toward a unified view. MIS $Q$. 2003, 27, 425-478. [CrossRef]

18. Venkatesh, V.; Thong, J.Y.; Xu, X. Consumer acceptance and use of information technology: Extending the unified theory of acceptance and use of technology. MIS Q. 2012, 36, 157-178. [CrossRef]

19. Davis, F.D. Perceived usefulness, perceived ease of use, and user acceptance of information technology. MIS Q. 1989, 13, 319-340. [CrossRef]

20. Venkatesh, V.; Davis, F.D. A theoretical extension of the technology acceptance model: Four longitudinal field studies. Manag. Sci. 2000, 46, 186-204. [CrossRef]

21. Fishbein, M.; Ajzen, I. Belief, Attitude, and Behavior: An Introduction to Theory and Research; Addison Wessley: Boston, MA, USA, 1975.

22. Ajzen, I. The theory of planned behavior. Organ. Behav. Hum. Decis. Process. 1991, 50, 179-211. [CrossRef]

23. Csirmaz, É.; Pető, K. International trends in recreational and wellness tourism. Procedia Econ. Finance 2015, 32, 755-762. [CrossRef]

24. Garge, G.K.; Balakrishna, C.; Datta, S.K. Consumer health care: Current trends in consumer health monitoring. IEEE Consum. Electron. Mag. 2017, 7, 38-46. [CrossRef]

25. Voigt, C.; Pforr, C. Wellness Tourism: A Destination Perspective; Routledge: Abingdon, UK, 2013.

26. Huh., C.; Lee, M.J.; Lee, S. A profile of Spa-goers in the US luxury hotels and resorts: A posteriori market segmentation approach. J. Hosp. Mark. Manag. 2019, 1-21. [CrossRef]

27. Chen, J.S.; Prebensen, N. Wellness as tourist motivation: Case of Taiwan. In Wellness and Tourism: Mind, Body, Spirit, Place; Bushell, R., Sheldon, P.J., Eds.; Cognizant Communication Corporation: New York, NY, USA, 2009; pp. 231-238.

28. Rátz, T. Zennis és Lomi Lomi, avagy új trendek az egészségturizmusban. In Egészégturizmus; Aubert, A., Csapó, J., Eds.; Bornus Nyomda: Pécs, Hungary, 2004.

29. Kamata, H.; Misui, Y. The difference of Japanese spa tourists' motivation in weekends and weekdays. Procedia Soc. Behav. Sci. 2015, 175, 210-218. [CrossRef]

30. Radnic, R.; Gracan, D.; Fister, M. Repositioning of thermal spa tourism of North-West Croatia in accordance with the European thermal spa tourism trends. Tour. Hosp. Manag. 2009, 15, 73-84.

31. Campón-Cerro, A.M.; Di-Clemente, E.; Hernández-Mogollón, J.M.; Folgado-Fernández, J.A. Healthy Water-Based Tourism Experiences: Their Contribution to Quality of Life, Satisfaction and Loyalty. Int. J. Environ. Res. Public Health 2020, $17,1961$. [CrossRef] [PubMed]

32. Koskinen, V.; Wilska, T.A. Identifying and understanding spa tourists' wellness attitudes. Scand. J. Hosp. Tour. 2018, 19, 259-277. [CrossRef]

33. Kamenidou, I.; Mamalis, S.; Priporas, C.V.; Samara, I. Motivations for Visiting Smokovo's Thermal Springs. In Proceedings of the 4th International Conference on Contemporary Marketing Issues (ICCMI), Heraklion, Greece, 22-24 June 2016.

34. Valentine, N.A. Wellness Tourism: Using Tourists' Preferences to Evaluate the Wellness Tourism Market in Jamaica. Rev. Soc. Sci. 2016, 1, 25-44. [CrossRef]

35. Hsieh, M.-T. Understanding mature traveller's demand and choice in spring destination. In Health, Wellness and Tourism: Healthy Tourists, Healthy Business? Proceedings of the Travel and Tourism Research Association Europe Annual Conference, Budapest, Hungary, 1-3 September 2010; Puczkó, L., Ed.; Travel and Tourism Research Association Europe: Dalarna, Sweden, $2010 ;$ pp. 85-91.

36. Lee, C.F.; King, B.E. Using the Delphi method to assess the potential of Taiwan's hot springs tourism sector. Int. J. Tour. Res. 2008, 10, 341-352. [CrossRef]

37. Mosquera, A.; Juaneda-Ayensa, E.; Olarte-Pascual, C.; Pelegrín-Borondo, J. Key Factors for In-Store Smartphone Use in an Omnichannel Experience: Millennials vs. Nonmillennials. Complexity 2018, 1057356. [CrossRef]

38. Assaker, G.; Hallak, R.; El-Haddad, R. Consumer usage of online travel reviews: Expanding the unified theory of acceptance and use of technology 2 model. J. Vacat. Mark. 2020, 26, 149-165. [CrossRef]

39. Mejia, C. Influencing green technology use behavior in the hospitality industry and the role of the "green champion". J. Hosp. Mark. Manag. 2018, 28, 538-557. [CrossRef]

40. Hall, C.M.; Voigt, C.; Brown, G.; Howat, G. Wellness tourists: In search of transformation. Tour. Rev. 2011, 66, 16-30. [CrossRef]

41. Kucukusta, D.; Guillet, B.D. Measuring Spa-goers' preferences: A conjoint analysis approach. Int. J. Hosp. Manag. 2014, 41, 115-124. [CrossRef]

42. Han, H.; Kiatkawsin, K.; Jung, H.; Kim, W. The role of wellness Spa tourism performance in building destination loyalty: The case of Thailand. J. Travel Tour. Mark. 2018, 35, 595-610. [CrossRef]

43. Alén, M.E.; Fraiz, J.A.; Rufín, R. Analysis of health Spa customers' expectations and perceptions: The case of Spanish establishments. Tékhne Rev. Estud. Politécnicos 2006, 5, 245-262.

44. Chiu, T.M.; Ku, B.P. Moderating effects of voluntariness on the actual use of electronic health records for allied health professionals. JMIR Med. Inform. 2015, 3, e7. [CrossRef]

45. Yoon, S.; Kim, J.; Connolly, D.J. Understanding motivations and acceptance of location-based services. Int. J. Hosp. Tour. Adm. 2017, 19, 187-209. [CrossRef] 
46. Klaysung, C. Behaviors and Factors Affecting the Selection of Spa Services among Consumers in Amphawa, Samut Songkhram, Thailand. Int. J. Soc. Behav. Educ. Econ. Bus. Ind. Eng. 2016, 10, 3897-3901.

47. Baabdullah, A.M.; Alalwan, A.A.; Rana, N.P.; Kizgin, H.; Patil, P. Consumer use of mobile banking (M-Banking) in Saudi Arabia: Towards an integrated model. Int. J. Inf. Manag. 2019, 44, 38-52. [CrossRef]

48. Brown, S.A.; Venkatesh, V. A model of adoption of technology in the household: A baseline model test and extension incorporating household life cycle. Manag. Inf. Syst. Q. 2005, 29, 11. [CrossRef]

49. Kim, S.H.; Kim, S.; Huh, C.; Knutson, B. A predictive model of behavioral intention to spa visiting: An extended theory of planned behavior. ICHRIE Conf. 2010, 19157531, 1-9.

50. Voigt, C.; Howat, G.; Brown, G. Hedonic and eudaimonic experiences among wellness tourists: An exploratory enquiry. Ann. Leis. Res. 2010, 13, 541-562. [CrossRef]

51. Johanson, M.M. Health, wellness focus within resort hotels. Hosp. Rev. 2004, 22, 3.

52. Pelegrín-Borondo, J.; Arias-Oliva, M.; Olarte-Pascual, C. Emotions, price and quality expectations in hotel services. J. Vacat. Mark. 2016, 23, 322-338. [CrossRef]

53. Ding, M.; Ross, W.T., Jr.; Rao, V.R. Price as an indicator of quality: Implications for utility and demand functions. J. Retail. 2010, 86, 69-84. [CrossRef]

54. Downward, P.; Lera-Lopez, F.; Rasciute, S. The zero-inflated ordered probit approach to modelling sports participation. Econ. Model. 2011, 28, 2469-2477. [CrossRef]

55. Downward, P.; Lera-Lopez, F.; Rasciute, S. The correlates of sports participation in Europe. Eur. J. Sport Sci. $2014,14,592-602$. [CrossRef]

56. Kucukusta, D.; Pang, L.; Chui, S. Inbound travelers' selection criteria for hotel Spas in Hong Kong. J. Travel Tour. Mark. 2013, 30, 557-576. [CrossRef]

57. Virabhakul, V.; Huang, C.H. Effects of service experience on behavioral intentions: Serial multiple mediation model. J. Hosp. Mark. Manag. 2018, 27, 1-20. [CrossRef]

58. Brey, E.T.; Lehto, X.Y. The relationship between daily and vacation activities. Ann. Tour. Res. 2007, 34, 160-180. [CrossRef]

59. Carr, N. The tourism-leisure behavioural continuum. Ann. Tour. Res. 2002, 29, 972-986. [CrossRef]

60. Chang, S.; Gibson, H.J. The relationships between four concepts (involvement, commitment, loyalty, and habit) and consistency in behavior across leisure and tourism. Tour. Manag. Perspect. 2015, 13, 41-50. [CrossRef]

61. Aarts, H.; Verplanken, B.; Van Knippenberg, A. Habit and information use in travel mode choices. Acta Psychol. 1997, 96, 1-14. [CrossRef]

62. Wood, W.; Tam, L.; Witt, M.G. Changing circumstances, disrupting habits. J. Pers. Soc. Psychol. 2005, 88, 918-933. [CrossRef] [PubMed]

63. Cervera, F.B.; Serrano, R.U.; Vico, C.G.; Milla, M.T.; García, M.M. Food habits and nutritional assessment in a university population. Nutr. Hosp. 2013, 28, 438-446.

64. Shanafelt, T.D.; Oreskovich, M.R.; Dyrbye, L.N.; Satele, D.V.; Hanks, J.B.; Sloan, J.A.; Balch, C.M. Avoiding burnout: The personal health habits and wellness practices of US surgeons. Ann. Surg. 2012, 255, 625-633. [CrossRef] [PubMed]

65. Turgalicia. Available online: https://www.turismo.gal/inicio (accessed on 8 January 2018).

66. Dijkstra, T.K.; Henseler, J. Consistent Partial Least Squares Path Modeling. MIS Q. 2015, 39, 297-316. [CrossRef]

67. Gefen, D.; Rigdon, E.E.; Straub, D.W. An update and extension to SEM guidelines for administrative and social science research. MIS Q. 2011, 35, 3-14. [CrossRef]

68. Henseler, J.; Ringle, C.M.; Sinkovics, R.R. The use of partial least squares path modeling in international marketing. Adv. Int. Mark. 2009, 20, 277-319.

69. Hair, J.F.; Ringle, C.M.; Sarstedt, M. Partial least squares structural equation modeling: Rigorous applications better result and higher acceptance. Long Range Plan. 2013, 46, 1-12. [CrossRef]

70. Chin, W.W. Issues and opinion on structural equation modelling. Manag. Inf. Syst. Q. 1998, 22, 7-15.

71. Petter, S.; Straub, D.W.; Rai, A. Specifying formative constructs in information systems research. MIS Q. 2007, 31, 623. [CrossRef]

72. Falk, R.F.; Miller, N.B. A Primer for Soft Modeling; University of Akron Press: Akron, OH, USA, 1992.

73. Pelegrín-Borondo, J.; Araújo-Vila, N.; Fraiz-Brea, J.A. Comparison of Spa Choice between Wellness Tourists and Healthcare/Medical Tourists. Healthcare 2020, 8, 544. [CrossRef] [PubMed]

74. García-Milon, A.; Martínez-Ruiz, M.P.; Olarte-Pascual, C.; Pelegrín-Borondo, J. Does the product test really make a difference? Evidence from the launch of a new wine. Food Qual. Prefer. 2019, 71, 422-430. [CrossRef]

75. Kowalczyk-Anioł, J.; Nowacki, M. Factors influencing Generation Y's tourism-related social media activity: The case of Polish students. J. Hosp. Tour. Technol. 2020, 11, 543-558. [CrossRef] 